J. Egypt. Soc. Parasitol. (JESP), 51(1), 2021: 175 - 182

(Online: 2090-2549)

\title{
THERAPEUTIC AND IMMUNO-MODULATORY EFFECT OF SILVER NANOPARTICLES-LOADED WITH METRONIDAZOLE ON EXPERIMENTAL BLASTOCYSTOSIS
}

\author{
By \\ DOAA A. AHMED ${ }^{1 *}$, NAGWA M. KAMAL ${ }^{1}$, AMAL A. MOHAMED ${ }^{1}$, \\ HALA E. ABDEL-HAMIED ${ }^{2}$ AND KHADYGA H. ABDELFADIL ${ }^{1}$
}

Departments of Medical Parasitology, and Histopathology ${ }^{2}$, Faculty of Medicine for Girls Al-Azhar University, Nasr City, Post Code: 11884, Egypt

(Correspondence: doaaamer85@yahoo.com).

Abstract

Blastocystis is one of the commonest enteric protozoa in many hosts. This study evaluated the effect of silver nanoparticles (AgNps) loaded with metronidazole (MTZ) on mice infected with Blastocystis. They were subjected to parasitological, histopathological, immunological, and immunohistochemical studies. The parasitological results revealed a powerful effect of $\mathrm{Ag}$ NPs loaded with MTZ over either MTZ or Ag Nps; where the reduction of cysts count in stool were $(90.7 \%, 87.33 \% \& 59.33 \%)$ respectively as compared to infected non-treated group. Histopathological results showed that AgNPs loaded with MTZ were the best in reducing inflammatory changes followed by MTZ then AgNPs. Regarding IgA, IgM \& IgG, Ag NPs loaded with MTZ treated mice showed the best result followed by MTZ treated mice then Ag NPs treated mice; where the reduction of mean concentration of IgA were $(30.5 \%, 26.24 \%$ \& $2.13 \%)$ respectively, while that of IgM were $(15.2 \%, 12.8 \% \& 2.8 \%)$ respectively and $\operatorname{IgG}$ were $(23.1 \%, 12.3 \% \& 5.2 \%)$ respectively as compared to infected non-treated group. The synergistic effect of both Ag NPS \& MTZ provoked the best reduction of CD3 \& CD20 expression and augmented counter modulation of the immune response to restore normal immune homeostasis.

Key wards: Blastocystis, Metronidazole, Silver nanoparticles, Experimental mice

\section{Introduction}

Blastocystis spp. proved to be one of the commonest enteric protozoa in man and other hosts (Batista et al, 2017). Blastocystis infection is globally prevalent parasite, affecting more than 1 billion peoples worldwide (Andersen and Stensvold, 2016). In Egypt, the prevalence was $16.7 \%$ by Elnazer et al. (2017) and $1.8 \%$ by El Drawany et al. (2019). Subtype 3 was the prevalent zoonotic one worldwide, with a controversy in its pathogenic potential (Lepczynska and Dzika, 2019). Blastocystosis may be asymptomatic or presented with enteric symptoms, as nausea, vomiting, diarrhea, or constipation, abdominal pain, bloating and irritable bowel syndrome or urticaria and rashes (Rendragraha et al, 2019). This depended on the parasite virulence and host immune status. The gut is rish with many immune cells, predominatly intraepithelial, B \& T lymphocytes as the main effector cells that interact with epithelial cells to allow normal homeostasis (Valsecchi et al, 2004). B cells are the main one for humoral immunity producing antibodies in response to antigenic stimulation, develop to memory B cells, act as antigen-presenting cells $\&$ secrete signaling cytokines as well (Mauri and Bosma, 2012). T lymphocytes play a central role in cell-mediated immunity (Terabe and Berzofsky, 2008). As Blastocystis efficiently adheres to the intestinal epithelial cells, excreting cysteine protease enzymes (Puthia et al, 2005; Wawrzyniak et al, 2013); it affects the gut immune homeostasis, initiating immunological reactions that include cellular and humoral immune responses with activation of T \& B lymphocyte, secretion of cytokines, immunoglobulins \& antimicrobial peptides (Yason et al, 2016). CD3 \& CD20 used by immunohistochemical staining as markers of tissue $\mathrm{T} \& \mathrm{~B}$ lymphocytes respectively ( $\mathrm{Abu}$ El-Fetouh et al, 2015).

Despite the controversy of pathogenicity, the symptoms have presupposed treatment if became persistent without other detected pathogens (Mokhtar et al, 2016). Many anti- 
protozoal drugs either single or in combination with others gave high failure rates (Le Busque et al, 2018). Although metronidazole (MTZ) is a golden blastocystosis treatment, yet with wide range of side effects as carcinogenicity, embryogenicity and teratogenicity, as well as variable inappropriate responses ranged from 0 to $100 \%$ (Batista et al, 2017).

Nanomedicine is the nanotechnology implementation for diagnosis, treatment, prevention and control of diseases (Abaza, 2016). Silver nanoparticles (Ag NPs) proved effective against both extracellular and intracellular parasites (Adeyemi et al, 2018). It significantly decreased the Cryptosporidium parvum oocysts count and viability in a safe, effective and cheap manner (Hassan et al, 2019).

In the present study, Ag NPs loaded with MTZ was evaluated for the augmented therapeutic and immune modulating effects on Albino mice infected with Blastocystis.

\section{Material and Methods}

Blastocystis spp. culture was kindly obtained from Parasitology Department, Ain Shams Faculty of Medicine, and was sub-passaged on Jones' medium, isolated and infective inoculum was prepared as 10.000/ml.

Drug: Metronidazole (MTZ, Sanofi Aventis Co., Cairo) stock solution of $1 \mathrm{mg} / \mathrm{ml}$ was prepared as $120 \mu \mathrm{g} / \mathrm{ml}$ for oral syrup (Mokhtar et al, 2016), and Ag NPs was synthesized (Mulfinger et al, 2007). Ag NPs loaded with MTZ: were prepared by adding $2 \mathrm{mg} / \mathrm{ml} \mathrm{Ag}$ NPs solution to $100 \mathrm{mg} / \mathrm{ml}$. MTZ.

Experimental animals: Fifty male clean laboratory bred 7 weeks old \& $20 \mathrm{gm}$ weight Swiss Albino mice were purchased from Tudor Bilharz Research Institute, Giza. They were handled under conventional conditions according to National Institutes of Health guidelines for animal experimentation, and approved by the Ethical Committee at Faculty of Medicine for Girls, Al-Azhar University.

Experimental design: Mice were divided into five groups of 10 mice each. G1: Heal- thy controls, G2: Infected untreated controls, G3: Infected MTZ-treated, G4: Infected Ag NPs treated and G5: Infected and treated by Ag NPs loaded with MTZ. Mice were infected with 10,000 cysts of Blastocystis/mouse by oral gavage (Ismail et al, 2016). To prove infection, fresh stool samples were collected from each one on $4^{\text {th }}$ day post infection (PI) for microscopic examination. Two weeks PI, G3, G4 \& G5 were treated with MTZ as $120 \mu \mathrm{g} / \mathrm{kg} /$ day (Fahmy et al, 2015), Ag NPs as $25 \mu \mathrm{g} / \mathrm{kg} /$ day (Mulfinger et al, 2007), and Ag NPs loaded with MTZ $(120 \mu \mathrm{g} / \mathrm{kg} /$ day $)$ respectively for 10 consecutive days.

Drugs' efficacy: All groups were sacrificed by neck rapid decapitation 4 weeks PI for examinations.

Parasitological examination: Intestinal contents were evacuated by gentle scraping and stools were collected to count Blastocystis by direct wet mount (unstained and iodine stained), and formal ether concentration technique (Garcia and Bruckner, 2007).

Histopathological examination: $1 \mathrm{~cm}$ colon segment was excised, opened, fixed in $10 \%$ formalin, embedded in paraffin blocks, sectioned at 4 to $5 \mu \mathrm{m}$ thickness, mounted on slides, stained by $\mathrm{H} \& \mathrm{E}$ and examined microscopically (Drury et al, 1967).

Immunological examination: Anti-Blastocystis antibodies; IgA, IgM \& IgG levels were evaluated by indirect ELISA using crude Blastocystis antigen (Engvall and Perlmann, 1971).

Immunohistochemical examination (IHC): Done on 2 separate sections from each group by CD3 mouse monoclonal antibody $(1 / 50$, code M7254, clone F7. 2.38) or CD20 mouse monoclonal antibody $(1 / 200$, code $\mathrm{M} 0$ 755 , clone L26), then incubation with labeled polymer by using 2 sequential $30 \mathrm{~min}$. incubation (En-Vision \& System-HRP, code K4006; Dako Denmark A/S).

Final reaction was obtained by $10 \mathrm{~min}$ incubation with 3, 3' diaminobenzidine \& substrate chromogen as brown colored precipitate at antigen site after the manufacturer's instructions. Slides were digitized by an Ol- 
ympus microscope with $1 / 2 \times$ photo adaptor, using 100x. Images were analyzed on an Intel Core I3- based computer by using video test morphology software (Russian Federation, Saint-Petersburg), for immuno-histologic analysis for stain density.

Statistical analysis: Data were analyzed by SPSS program (statistical package of social science, SPSS Inc., Chicago, IL, USA) version 16 for Microsoft Windows. Mean and standard deviation measured central tendency and quantitative data dispersion. Student ttest compared between groups. Significance was at $\mathrm{P}<0.05$ with confidence level $95 \%$.

\section{Results}

Parasitological: Ag NPs loaded with MTZ gave the best result (Tab.1) followed MTZ then Ag NPs; where the reduction of Blastocystis cyst mean count $/ \mathrm{ml}$ intestinal fluid were $90.7 \%, 87.33 \%$ and $59.33 \%$ respectively, compared to infected non treated group with significance $(\mathrm{P}<0.05)$.

Table 1: Blastocystis cysts $/ \mathrm{ml}$ of intestinal fluid and $\%$ of reduction in all studied groups.

\begin{tabular}{|l|c|c|c|c|}
\hline Groups & Mean \pm SD & T-test & P value & Reduction $\%$ \\
\hline Infected non treated & $2500 \pm 500$ & & & \\
\hline MTZ treated & $316.7 \pm 175.6$ & 7.1 & $0.002^{*}$ & 87.33 \\
\hline Ag NPs treated & $1016.7 \pm 500.8$ & 3.6 & $0.022^{*}$ & 59.33 \\
\hline Ag NPs loaded with MTZ treated & $233.33 \pm 144.34$ & 7.5 & $0.002^{*}$ & 90.7 \\
\hline
\end{tabular}

*Significant difference $(\mathrm{P} \leq 0.05)$.

Histopathological: Infected non-treated intestine showed large number of Blastocystis in lumen, glands and sub-mucosa. Mucosa showed ulceration, villous atrophy and disturbed crypt-villous ratio with chronic inflammatory infiltrates. The group treated with Ag NPs loaded with MTZ gave the best result as it showed very few Blastocystis in glands, with normal structure of mucosa, lamina propria, and normal crypt-villous ratio, followed by group treated with MTZ and the least was Ag NPs treated ones. The IgA, IgM \& IgG: Ag NPs loaded with MTZ treated group showed the best cure rate followed by MTZ treated group then Ag NPs treated group; where the percentages of reduction of mean concentration of Ig A (pg) / $\mathrm{ml}$ serum were $(30.5 \%, 26.24 \% \& 2.13 \%)$ respectively and that of $\operatorname{IgM}$ were $(15.2 \%, 12.8 \%$ \& $2.8 \%)$ respectively, but $\operatorname{IgG}$ were $(23.1 \%$, $12.3 \% \& 5.2 \%)$ respectively compared to positive control, with significant difference in $\mathrm{G} 3$ \& G5 $(\mathrm{P}<0.05)$.

IHC sections showed different expression of intraepithelial lymphocytes (IELs) infiltrated within crypts and Struma using CD3 \& CD20 (Figs. 1, 2, 3, 4, 5, 6, 7, 8, 9, 10, 11, $12,13,14,15 \& 16)$.

Table 2: IgA, IgM \&IgG evaluation in studied groups by indirect ELISA

\begin{tabular}{|c|c|c|c|c|}
\hline \multicolumn{2}{|c|}{$\begin{array}{l}\text { immunogtobthins } \\
\text { groups }\end{array}$} & $\operatorname{IgA}$ & IgM & $\operatorname{IgG}$ \\
\hline normal & mean $\pm \mathrm{SD}$ & $9.03 \pm 1.1$ & $437.67 \pm 30$ & $672 \pm 24.27$ \\
\hline infected non treated & mean $\pm \mathrm{SD}$ & $14.1 \pm 2.3$ & $579.3 \pm 21.03$ & $987.7 \pm 22$ \\
\hline \multirow[t]{4}{*}{ MTZ treated } & mean \pm SD & $10.4 \pm 0.7$ & $505.3 \pm 6.51$ & $866 \pm 45.83$ \\
\hline & t-test & 2.7 & 5.8 & 4.15 \\
\hline & p. value & $0.05^{*}$ & $0.004 *$ & $0.014 *$ \\
\hline & $\%$ of reduction & $26.24 \%$ & $12.8 \%$ & $12.3 \%$ \\
\hline \multirow[t]{4}{*}{ Ag NPs treated } & mean $\pm \mathrm{SD}$ & $13.8 \pm 0.9$ & $563 \pm 46.1$ & $936 \pm 55.75$ \\
\hline & t-test & 0.2 & 0.56 & 1.5 \\
\hline & p. value & 0.8 & 0.61 & 0.21 \\
\hline & $\%$ of reduction & $2.13 \%$ & $2.8 \%$ & $5.2 \%$ \\
\hline \multirow{4}{*}{ Ag NPs loaded with MTZ treated } & mean \pm SD & $9.8 \pm 1.3$ & $491.3 \pm 10$ & $760 \pm 51.6$ \\
\hline & t-test & 2.8 & 6.5 & 7.02 \\
\hline & p. value & $0.05^{*}$ & $0.003 *$ & $0.002 *$ \\
\hline & $\%$ of reduction & $30.5 \%$ & $15.2 \%$ & $23.1 \%$ \\
\hline
\end{tabular}

Discussion

Effective treatment of symptomatic blastocystosis only without other pathogenic age- nts became a great challenge since the failure of metronidazole and other remedies (Roberts et al, 2014, Batista et al, 2017). 
Metal NPs were loaded with several drugs, e.g. praziquantel, rifampicin, amphotericin $\mathrm{B}$, chloroquine and albendazole in the treatment of different parasitic infection e.g. schistosomiasis, malaria, leishmaniasis and visceral larva migrans (Abaza, 2016). The present study explored the effectiveness of AgNPs loaded with MTZ on experimental blastocystosis by parasitological, histopathological, immunological and immunohistochemical examinations. To the best of the available knowledge, this is the first study in which blastocystosis was treated with Ag NPs loaded with MTZ

Blastocystis expresses cysteine proteases, which play a crucial role in host cells invasion (Amaya et al, 2015), facilitated by connective tissue and extracellular matrix proteins degradation. These proteases affect the epithelial integrity, causing intestinal inflammations, damage and increased permeability in experimental model (Puthia et al, 2005; Basyoni et al, 2018). In the present work, histopathological examination of the infected non treated group revealed detrimental effects on the intestinal mucosa; including villous shortening, atrophy and infiltration of lamina propria with inflammatory cells. Blastocystis were detected within the lumen and in the villi. This is in agreement with Ismail et al. (2016) and Basyoni et al., (2018). Also, there was increased production of the three tested anti- Blastocystis antibody isotypes, $\operatorname{IgA}$, IgM, and $\mathrm{IgG}$ in serum of the infected non treated group in comparison of the non-infected control group. This agreed with Zierdt et al. (1995) who reported that IgG was elevated in 25 of 28 Blastocystis infected humans in a study conducted by ELISA, Hussain et al. (1997) who reported significant increase in IgG2 antibody in irritable bowel syndrome patients infected with Blastocystis, and Kaneda et al. (2000) found that serum Ig A, IgM \& IgG in $70 \%$ of infected asymptomatic individuals. But, Chen et al. (1987) found lack of specific antibody response in patients with Blastocystis caused intermittent diarrhea. It is supposed that the antibodies production is a response to surface coat fragments of Blastocystis that was transported from the gut lumen to tissue lymphocytes (Hussain et al, 1997). Tan et al. (2002) reported that this surface coat might act as immunological barrier to protect the parasite by promoting production of ineffective $B$ cells that produce non-functioning immunoglobulins. Blastocystis-secreted cysteine proteases were immunogenic that controlled and modulated the host immune system by degradation of secretory IgA (Puthia et al, 2005: Rendragraha et al, 2019).

CD3 is a protein structure on the surface of $\mathrm{T}$ lymphocytes, associated with T-cell receptor (TCR) complex (Yang et al, 2005), while CD20 is a protein expressed on B cells surface (Nadler et al, 1981). The CD3 \& CD20 expressed in the infected untreated group was increased as compared to non-infected control. This agreed with Abu El-Fetouh et al. (2015) who found higher CD3 and CD20 mean cell counts in the infected compared to control mice. The surface coat fragments of Blastocystis secreted proteases and cytokines transported from the gut lumen to the tissue stimulate multiple immune cells including $\mathrm{T} \& \mathrm{~B}$ lymphocytes (Long et al, 2001). Iguchi et al. (2009) reported that the increased transcription of IFN- $\gamma$, IL-12, \& TNF- $\alpha$ in mucosa of Blastocystis infected rats, and that the parasites enhanced the activation (or influx) of T cells, B cells, and other immune cells in local tissues.

In the present study, Ag NPs loaded with MTZ showed a powerful effect over either MTZ or Ag NPs. The counts of Blastocystis cysts were greatly reduced, histopathological inflammatory changes were markedly improved, with marked reduction in Igs levels and the best distribution of CD3 and CD20 found in group treated by Ag NPs loaded with MTZ. These results may be attributed to the intelligent design at the Nano scale that yields a compound including drug Nano carrier for efficient drug delivery. Nano carriers have many advantages including its small size, which overcomes physiological 
barriers and facilitates cells entry. Increased its solubility improves bioavailability and ability to be delivered to the target sites with controlled release (Karunaratne, 2007). MTZ gave an acceptable effect with moderate Blastocystis cysts count reduction, moderate improvement of histopathological inflammatory changes and the immunological response. This was in accordance with the results of Basyoni et al. (2018) who reported (79.3\%) percentage of reduction of Blastocystis cysts count and moderate improvement of inflammatory reactions and Fahmy et al. (2019) who reported $83 \%$ percentage of reduction and repairing of the histopathological changes; with MTZ treatment of experimental blastocystosis. On the other hand, Roberts et al. (2014) reported complete failure of MTZ and reported that it should no longer be considered the recommended treatment for Blastocystis infection. Also, Batista et al. (2017) found inadequate response to MTZ and their systematic review showed greatly variable responses to MTZ treatment ranging from $0 \%$ to 100 . This variability may be due to differences in drug resistance, Blastocystis subtypes, technical methods or geographical conditions.

Ag NPs was the least effective in the present study. Ahmed et al. (2015) were the first to study the effect of Ag NPs on Blastocystis where it gave in vitro percentage of growth inhibition slightly higher than or comparable to MTZ. Adeyemi et al. (2018) reported moderate in vitro anti $T$ gondii effect of Ag NPs and great selective in vitro anti trypanosomal effect, but only trypanostatic effect in vivo. Gopinath et al. (2017) stated that Ag NPs interact with bacterial membranes by either adhesion and/or penetration into the membrane bilayers, affecting its integrity and cause intracellular protein and electrolytes leakage. This represents an evidence of apoptosis in Blastocystis upon treatment with Ag NPs (Huppertz et al, 1999). Cameron et al. (2016) reported that its mechanism of action is a dual effect where the nanoparticles of silver interact with the cell wall, damaging it and the $\mathrm{Ag}^{+}$ions get entrance into the cyst destroying it. It is proved that Ag NPs have different targets in the parasite and that generation of reactive oxygen species contributes greatly to its anti-parasitic effect (Adeyemi et al, 2018). Although Ag NPs are less effective than MTZ, yet it has the advantage of being naturally safe compounds, with no cytotoxicity in suitable doses on human cells (Ahmed et al, 2015).

The synergistic effect of both Ag NPS and MTZ provoked the best results in reduction of CD3 and CD20 levels and augmented counter modulation of the immune response to restore normal immune homeostasis

\section{Conclusion}

AgNPs loaded with MTZ efficiently treated blastocystosis and improved immunological pictures as promising therapeutic agent for human infection. Not all lymphocytic infiltrates of CD3 \& CD20 in the colon epithelium were lymphocytic colitis especially in man. So, physician must evaluate treatment.

\section{References}

Abaza, S, 2016: Applications of nanomedicine in parasitic diseases. PUJ 9:1-6.

Abu El-Fetouh, N, Abdelmegeed, E, Attia, R, El-Dosoky, I, Azab, M 2015: Genotyping of $B l$ astocystis hominis symptomatic isolates and kinetics of associated local CD3 \& CD20 cell infiltrate. PUJ 8:115-22.

Adeyemi, OS, Molefe, NI, Awakan, OJ, Nwonuma, CO, Alejolowo, OO, et al, 2018: Metal nanoparticles restrict the growth of protozoan parasites. Artif. Cells Nanomed. Biotechnol. 46: S86-94.

Ahmed, MAF, Ismail, KA, Ahmed, SAEG, Ibrahim, AN, Gohar, YM, 2015: In vitro activity of curcumin and silver nanoparticles against Blastocystis hominis. Infect. Dis. Clin. Pract. 23: 135-40.

Amaya, AM, Trejos, J, Morales, E, 2015: Blastocystis spp.: Revisión literaria de un parásito intestinal altamente prevalente. Rev. Salud UIS 47:Pages

Andersen, LOB, Stensvold, CR, 2016: Blastocystis in health and disease: Are we moving JCM 54:524-8.

Arisue, N, Hashimoto, T, Yoshikawa, H, Nakamura, Y, Nakamura, G, et al, 2002: Phyloge- 
netic position of Blastocystis hominis and of stramenopiles inferred from multiple molecular sequence data. J. Eukaryot. Microbiol. 49:42-53. Baggiolini, M, Loetscher, P, Moser, B, 1995: Interleukin- 8 and the chemokine family. Int. J. Immunopharmacol. 17:103-8.

Basyoni, MMA, Fouad, SA, Amer, MF, Amer, AF, Ismail, DI 2018: Atorvastatin: In-vivo synergy with metronidazole as anti-Blastocystis therapy. Korean J. Parasitol. 56:105-12.

Batista, L, Pérez, J, Rosinach, M, Gonzalo, V, Sainz, E, et al, 2017: Low efficacy of metronidazole in the eradication of Blastocystis hominis in symptomatic patients: Case series and systematic literature review. Gastroenterol. Hepatol. 40: 381-7.

Cameron, P, Gaiser, BK, Bhandari, B, Bartley, PM, Katzer, F et al, 2016: Silver nanoparticles decrease the viability of Cryptosporidium parvum oocysts. Appl. Environ. Microbiol. 82: 431-7.

Chen, J, Vaudry, W, Kowalewska, K, Wenman, W, 1987: Lack of serum immune response to Blastocystis hominis. Lancet 330:1021.

Cheroutre, H, Lambolez, F, Mucida, D, 2011: The light and dark sides of intestinal intraepithelial lymphocytes. Nat. Rev. Immunol. 11:44556.

Dogruman-Al, F, Kustimur, S, Yoshikawa, H, Tuncer, C, Simsek, Z, et al, 2009: Blastocystis subtypes in irritable bowel syndrome and inflammatory bowel disease in Ankara, Turkey. Mem. Inst. Oswaldo Cruz 104:724-7.

Drury, RAB, Wallington, EA, Cameron, SR, 1967: Carleton's Histological Technique, London.

El Drawany, ZE, Ahmed, SH, Etewa, SE, Ibrahim, SM, 2019: Prevalence of intestinal parasites among type 1 diabetic patients in pediatrics Zagazig University Hospital. Int. J. Endocrinol. Metab. 7: Pages

EInazer, MM, Shatat, MAS, Omran, EK, Ali, N, Ibrahim, MAL, et al, 2017: Blastocystis hominis infection and its relation with other intestinal parasites among outpatients, Sohag SMJ. journals.ekb.eg 21:429-36.

Engvall, E, Perlmann, P, 1971: Enzyme-linked immunosorbent assay (ELISA) quantitative assay of from a clinical to a public health perspective? immunoglobulin G. Immunochemistry 8: 871-4.

Fahmy, AM, Zalat, RS, Hegab, AM, Wafy, W A, 2019: Alterations in oxidative stress activities and trace elements levels on experimental blastocystosis. J. Gastroenterol. Hepatol. Res. 8: 3041-8.

Fahmy, ZH, Aly, E, Hammam, O, 2015: The role of artemether as a possible drug for treatment Blastocystis hominis infection: In vivo and in vitro studies. AJPP 9:893-9.

Garcia, L, Bruckner, D, 2007: Examination of other specimens from the intestinal tract and the urogenital system. In: Diagnostic Medical Parasitology. $5^{\text {th }}$ Ed., Asm Press, Washington DC.

Gopinath, V, Priyadarshini, S, Loke, MF, Arunkumar, J, Marsili, E, et al, 2017: Biogenic synthe-sis, characterization of antibacterial silver nanoparticles and its cell cytotoxicity. Arab. J. Chem. 10:1107-17.

Hassan, D, Farghali, M, Eldeek, H, Gaber, M, Elossily, N, et al, 2019: Antiprotozoal activity of silver nanoparticles against Cryptosporidium parvum oocysts: New insights on their feasibility as a water disinfectant. J. Microbiol. Meth. 165: 105698.

Huppertz, B, Frank, HG, Kaufmann, P, 1999: The apoptosis cascade,morphological and immuno-histochemical methods for its visualization. J. Anat. Embryol. 200:1-18.

Hussain, R, Jaferi, W, Zuberi, S, Baqai, R, Abrar, N, et al, 1997: Significantly increased IgG2 sub-class antibody levels to Blastocystis hominis in patients with irritable bowel syndrome. Am. J. Trop. Med. Hyg. 56:301-6.

Iguchi, A, Yoshikawa, H, Yamada, M, Kimata, I, Arizono, N, 2009: Expression of interferon gamma and proinflammatory cytokines in the cecal mucosa of rats experimentally infected with Blastocystis sp. strain RN94-9. Parasitol. Res. 105:135-9.

Ismail, S, Ali, I, Amer, N, Fahmy, Z, Azmy, M, Magdy, M, 2016: Susceptibility of Blastocystis hominis to monolaurine (Lauric acid), lactoferine (Lactobacillus acidophillus) and metronidazole: An in vitro and in vivo studies. AJPP 10: 14-25.

Kaneda, Y, Horiki, N, Cheng, XJ, Tachibana, H, Tsutsumi, Y, 2000: Serologic response to Blastocystis hominis infection in asymptomatic individuals. Recon No. 20010062704. Tokai J. Exp. Clin. Med. 25:51-6.

Karunaratne, DN, 2007: Nanotechnology in me-edicine. J. Nat. Sci. Fou. Sri Lanka 35, 3:149-52. Le Busque, A, Gunaratne, AW, Saxena, M, Pilarinos, D, Maistry, P, et al, 2018: Anti-protozoal enema treatment for Blastocystis hominis 
and Dientamoeba fragilis: Does volume matter? Am. J. Gastroenterol. 113:S62-3.

Lepczynska, M, Dzika, E, 2019: The influence of probiotic bacteria and human gut micro-organisms causing opportunistic infections on Blastocystis ST3. Gut Pathol.11:11.

Long, H, Handschack, A, König, W, Ambrosch, A, 2001: Blastocystis hominis modulates immune responses and cytokine release in colonic epithelial cells. Parasitol. Res. 87:1029-30.

Mauri, C, Bosma, A, 2012: Immune regulatory function of B cells. Ann. Rev. Immunol. 30:22141.

Mokhtar, AB, El-Gayar, EK, Habib, ES, 2016: In vitro anti-protozoal activity of propolis extract and cysteine proteases inhibitor (phenyl vinyl sulfone) on Blastocystis species. J. Egypt. Soc. Parasitol. 46, 2:261-72.

Mulfinger, L, Solomon, SD, Bahadory, M, Jeyarajasingam, AV, Rutkowsky, S, et al, 2007: Synthesis and study of silver nanoparticles. J. Chem. Educ. 84:322-4.

Nadler, L, Ritz, J, Hardy, R, Pesando, JM, Schlossman, S, et al, 1981: A unique cell surface antigen identifying lymphoid malignancies of B cell origin. J. Clin. Investig. 67:134-40.

Pescovitz, M 2006: Rituximab, an anti-CD20 monoclonal antibody: History and mechanism of action. Am. J. Transplant. 6:859-66.

Puthia, MK, Vaithilingam, A, Lu, J, Tan, KSW, 2005: Degradation of human secretory immunoglobulin A by Blastocystis. Parasitol. Res. 97:386-9.

Quintanilla-Martinez, L, Preffer, F, Rubin, D, Ferry, JA, Harris, NL 1994: CD20+ T-cell lymphoma: neoplastic transformation of a normal T-cell subset. Am. J. Clin. Pathol. 102:483-9.

Rendragraha, BW, Suwanti, L, Ernawati, R,
Koesdarto, S, et al, 2019: Characterization and production of polyclonal antibody anti excretory secretory protein of Blastocystis sp. Indian Vet. J. 96:30-2.

Renegar, K, Small, P, 1999: Passive immu-nization: Systemic and mucosal. In: Mucosal Immunology, $2^{\text {nd }}$ Ed., PL, Ogra, J, Mestecky, ME, Lamm, W, Strober, et al, eds. Academic, N.Y.

Roberts, T, Ellis, J, Harkness, J, Marriott, D, Stark, D, 2014: Treatment failure in patients with chronic Blastocystis infection. J. Med. Microbiol. 63:252-7.

Tan, KS, Singh, M, Yap, EH, 2002: Recent advances in Blastocystis hominis: Hot spots in terra incognita. Int. J. Parasitol. 32:789-804.

Terabe, M, Berzofsky, JA, 2008: The role of NKT cells in tumor immunity. Adv. Cancer Res. 101:277-48.

Valsecchi, R, Leghissa, P, Greco, V, 2004: Cutaneous lesions in Blastocystis hominis infection. Acta Derm. Venereol. 84:322-3.

Wawrzyniak, I, Poirier, P, Viscogliosi, E, Dionigia, M, Texier, C, et al, 2013: Blastocystis, an unrecognized parasite: An overview of pathogenesis and diagnosis. Ther. Adv. Infect. Dis. 1: 167-78.

Yang, H, Parkhouse, RM, Wileman, T, 2005: Monoclonal antibodies that identify the CD3 molecules expressed specifically at the sur-face of porcine $\gamma \delta$-T cells. J. Immunol.115:189-96.

Yason, JA, Ajjampur, SSR, Tan, KSW, 2016: Blastocystis isolate B exhibits multiple modes of resistance against antimicrobial peptide LL-37. Infect. Immun. 84:2220-32.

Zierdt, CH, Zierdt, WS, Nagy, B, 1995: Enzyme-linked immunosorbent assay for detection of serum antibody to Blastocystis hominis in symptomatic infections. J. Parasitol. Vol.127-9

\section{Explanation of figures}

Fig. 1 A\&B: Normal control intestinal section showed normal mucosa, lamina propria and normal intestinal crypt-villous ratio (H\&E, x200). Fig. 2: Intestinal section in infected non treated mice showed large number of Blastocystis in lumen of intestinal glands (black arrows). Boxed area showed magnified vacuolar forms of Blastocystis with four peripheral nuclei and central vacuole $(\mathrm{H} \& \mathrm{E} \times 400)$.

Fig. 3: Intestinal section in infected non treated mice showed large number of Blastocystis in lumen (red arrow) and glands crossing lamina propria to submucosa. Intestinal mucosa showed ulceration of lining epithelial cells (black arrow), broadening and disturbed crypt-villous ratio; Chronic inflammatory infiltrate in lamina and submucosa (yellow arrow) (H\&E, x200).

Fig. 4: Intestinal section in infected mice treated with MTZ showed mild number of Blastocystis in lumen (black arrow), mucosa with superficial erosions (red arrow) slight healing of mucosa and normal intestinal crypt-villous ratio (H\&E, x200).

Fig. 5: Intestinal section in infected mice treated with Ag NPs showed Blastocystis in lumen (black arrows), showed with dense inflammatory cell infiltrate (H\&E, x200).

Fig. 6: Intestinal section in infected mice treated with Ag NPs loaded with MTZ, showed few Blastocystis in glands only (black arrows), normal structure of mucosa, lamina propria and normal intestinal crypt-villous ratio (red arrow) (H\&E, $\mathrm{x} 400)$.

Fig. 7: Colonic section showed few scattered CD3cells in negative control (IHC 200x).

Fig. 8: Colonic section showed few scattered CD20cells in in negative control (IHC 200x).

Fig. 9: Dense CD3 in crypts and stromal tissue of infected untreated mice (IHC 400x).

Fig. 10: Dense CD20 in crypts and stromal tissue of infected untreated mice (IHC400x)

Fig. 11: Dense CD3 stromal and crypt infiltrates of infected and Ag NPs treated mice (IHC100x).

Fig. 12: Dense CD20 stromal and crypt infiltrates of infected and Ag NPs treated mice (IHC200x). 
Fig. 13: Moderate inflammatory cell infiltrate of CD3 of MTZ treated mice (IHC 400x).

Fig. 14: Moderate inflammatory cell infiltrate of CD20 of MTZ treated mice (IHC 200x)

Fig. 15: Improved mice showed few inflammatory cells of CD 3 in intestinal mucosa in Ag NPs loaded with MTZ treated mice (IHC 200x).

Fig. 16: Improved mice showed few inflammatory cells of CD20 in intestinal mucosa in Ag NPs loaded with MTZ treated mice (IHC 200x)
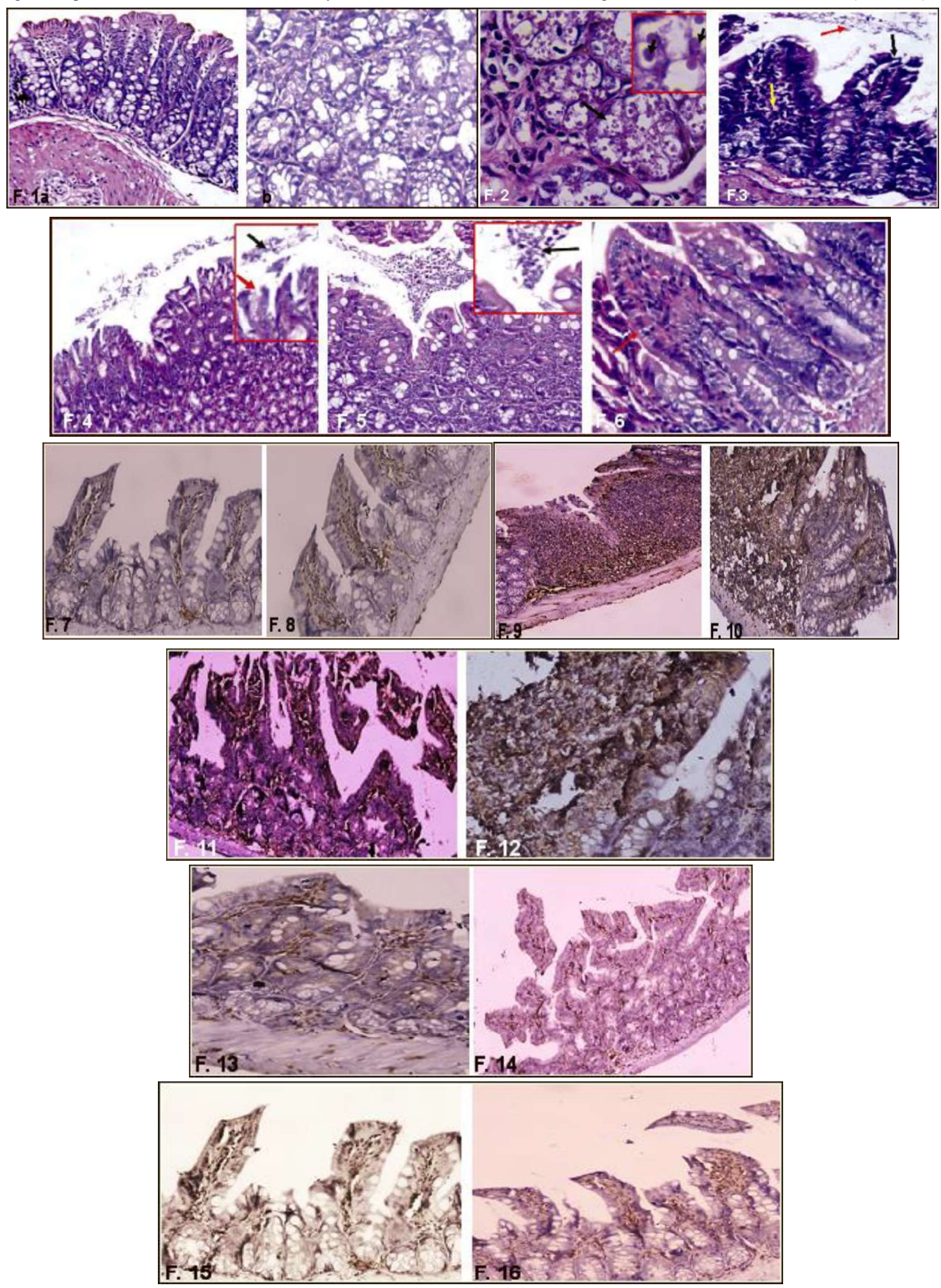